\title{
Lianas, tree ferns and understory species: indicators of conservation status in the Brazilian Atlantic Rainforest remnants, southeastern Brazil
}

\author{
A. C. D. Castello ${ }^{a *}$, S. Coelho ${ }^{b}$ and E. Cardoso-Leite \\ a Programa de Pós-graduação em Ciências Biológicas (Botânica), Universidade Estadual Paulista \\ "Júlio de Mesquita Filho" - UNESP, Rubião Júnior District, Botucatu, SP, Brazil \\ bPrograma de Pós-graduação em Sustentabilidade na Gestão Ambiental - PPGSGA-So, Universidade Federal de \\ São Carlos - UFSCar, Rod. João Leme dos Santos, SP 264, Km 110, Sorocaba, SP, Brazil \\ 'Departamento de Ciências Ambientais, Universidade Federal de São Carlos - UFSCar, Rod. João Leme dos Santos, \\ SP 264, Km 110, Sorocaba, SP, Brazil \\ *e-mail: carol.dcastello@gmail.com
}

Received: May 13, 2015 - Accepted: January 28, 2016 - Distributed: May 31, 2017

(With 3 figures)

\begin{abstract}
Indicators are applied faster and at lower costs than conventional surveys, providing quick and efficient responses that can facilitate protected areas management. Our aim was to select indicators from vegetation to monitor protected areas. For this purpose, we analyzed understory and quantified lianas and tree ferns in protected and non-protected areas, in order to find indicator species. Our study areas are located in Vale do Ribeira, southeastern São Paulo state, Brazil. One of the areas is under two protection categories (IUCN's categories II and V), and the other is a privately owned farm. Lianas with large diameters $(>13 \mathrm{~cm})$ and tree ferns with great heights $(>19 \mathrm{~m})$ were considered indicators of undisturbed areas (protected areas) because their growth is directly related to forest successional stage. Indicator species within the protected area were shade tolerant species, such as Bathysa australis (A.St.-Hil.) K.Schum., whereas outside the protected area were pioneer species, such as Pera glabrata (Schott) Poepp. ex Baill. e Nectandra oppositifolia Ness. All of the suggested indicators can be used in management actions, especially in protected areas, to guarantee forest maintenance and ensure fulfillment of the conservation objectives of these areas.
\end{abstract}

Keywords: successional stages, indicator species, protected areas, Brazilian Atlantic Rainforest.

\section{Lianas, fetos arborescentes e espécies de sub-bosque: indicadores do estado de conservação da Mata Atlântica brasileira}

\section{Resumo}

Os indicadores são aplicados com menores custos e mais rapidez em comparação com levantamentos convencionais, fornecendo respostas rápidas e eficientes que podem facilitar a gestão das áreas protegidas. Nosso objetivo foi selecionar indicadores de vegetação para monitorar áreas protegidas. Para este fim, analisamos o sub-bosque e quantificamos as lianas e fetos arborescentes em áreas protegidas e não-protegidas em busca de espécies indicadoras. Nossas áreas de estudo estão localizadas na região do Vale do Ribeira, sudeste do Estado de São Paulo, Brasil. Uma delas é uma área protegida (categorias da IUCN II e V) e outra uma fazenda de propriedade privada. Lianas com grandes diâmetros $(>13 \mathrm{~cm})$ e fetos arborescentes com grandes alturas $(>19 \mathrm{~m})$ foram considerados indicadores de áreas não perturbadas (área protegida), pois seu crescimento está diretamente associado com o estágio sucessional das florestas. As espécies indicadoras da área protegida são não pioneiras, como Bathysa australis (A.St.-Hil.) K.Schum., já as da fazenda (não protegida) são pioneiras, como Pera glabrata (Schott) Poepp. ex Baill. e Nectandra oppositifolia Ness. Todos indicadores sugeridos podem ser utilizados em ações de gestão e conservação, especialmente em áreas protegidas, para garantir a manutenção dos remanescentes florestais e para assegurar o cumprimento dos objetivos destas áreas.

Palavras-chave: estágios sucessionais, espécies indicadoras, áreas protegidas, Mata Atlântica.

\section{Introduction}

The Atlantic rainforest is one of the world's biodiversity hotspots, because of its great diversity of species, level of endemism and threat (Myers et al., 2000). The Atlantic rainforest remnants are highly fragmented, mostly as small 
and isolated patches (Ribeiro et al., 2009). The largest continuous area of this domain is located in Vale do Ribeira, southeastern São Paulo State, Brazil. The remnants represent approximately $50 \%$ of what have not been ravaged (Kronka et al., 2005) and the main strategy to conserve the Atlantic Rainforest's biodiversity is via protected area establishment (Gaston et al., 2006; Le Saout et al., 2013).

Human disturbances are undesirable in highly restrictive protected areas such as IUCN categories I and II. Disturbance type and intensity - vegetation removal for agricultural land use, selective logging, selective harvesting of economically important species (e.g. Palm trees), among others - can lead to species substitution and other structural changes (e.g. decrease in height and diameter of canopy species) and to a return to an earlier successional stage (Guariguata and Ostertag, 2001). Light exposure, temperature, humidity (Denslow, 1987), canopy layer (Tabarelli et al., 1999), litter cover (Regina, 2001) are variables that change along the forest successional process, affecting structure and species composition (Guariguata and Ostertag, 2001). Intermediate disturbances (Connell, 1978) also contribute to occurrence of certain species and they even increment species richness in certain areas. Disturbances occur at forest fragments edges or in the core (or between conserved and degraded areas). In addition, they can cause heterogeneous environmental conditions, which may positively influence diversity and complexity of the system (Rodrigues et al., 2007; Vale et al., 2009).

In order to maintain the ecological integrity of a forest, it is necessary to provide information about status, condition and conservation value of protected areas (Noss, 1999). Monitoring conservation status of protected areas (PA) is a promising tool for assessing whether conservation objectives have been achieved or not. This assessment tool may help to protect the Atlantic Rainforest remnants and in decision making to minimize potential problems over time (Butchart et al., 2010). However, there are few monitoring programs of PA and many of them are focused on management and infrastructure (ICMBio, 2011) and not on conservation status, e.g., meeting biodiversity conservation goals (Le Saout et al., 2013).

In developed countries there are guidelines to monitor biodiversity (Gardner, 2010; Parrotta et al., 2012), mostly focused on certified forests outside protected areas. In developing countries, however, we lack systematic programs to monitor PA conservation effectiveness (Terborg and Davenport, 2002; Gaston et al., 2006; Le Saout et al., 2013). In addition, the complexity of biodiversity makes it virtually impossible to monitor all species (Lindenmayer et al., 2000). Therefore, the use of indicators to assess vegetation conservation status can be a useful tool for monitoring these areas (Noss, 1990). The advantage of using indicators is that they can be applied faster and at lower costs than conventional surveys, providing quick and efficient responses that can facilitate protected areas management (Carignan and Villard, 2002).

Indicators are defined as a signature or sign of a biodiversity feature, with quantitative and/or qualitative features that translate in a simplified and useful way the biodiversity aspects (Duelli and Obrist, 2003). The indicators choice should be based on criteria such as aptitude and response to environmental characteristics, and they should allow hypotheses tests (McGeoch, 1998; Duelli and Obrist, 2003). To be effective, an indicator must: (1) be sensitive and respond to changes in the ecosystem caused by human disturbance, (2) allow easy and reliable identification, (3) be viable and have low implementation costs (Carignan and Villard, 2002; Pearce and Venier, 2006). Lindenmayer et al. (2000) also suggest that indicators are identified as: (1) taxon-based biodiversity indicators - indicator species that can be used as proxies for other biodiversity components or for changes in the ecosystem; or (2) structure-based indicators - forest structure features that can be used as proxies for changes in the ecosystem.

An ecological monitoring program aims to detect changes in the ecosystem, usually those of anthropogenic origin, which can degrade environmental quality. In forest ecosystems it is difficult to detect indicator species capable of signaling those changes, especially plant species, because they can resist to disturbances and maintain structure and function relatively intact (Walker and Salt, 2006). In this context, our aim was to select vegetation indicators to monitor protected areas in the Atlantic Rainforest. We analyzed the understory and quantified lianas and tree ferns in protected and non-protected areas, in order to search for indicator species. We also evaluated the influence of environmental characters (i.e., light, canopy cover, humidity and litter cover) on vegetation (i.e., lianas, tree ferns and understory species). We selected areas based on the assumption that vegetation remnants located within protected areas would be more conserved, and in an advanced successional stage (i.e. high levels of canopy cover, litter cover and humidity and low levels of light available) compared to vegetation outside protected areas.

\section{Material and Methods}

\subsection{Study areas}

This study was conducted in two different areas - a protected area (PA) and a non-protected area (NPA) which were approximately 65 kilometers apart, both in the Vale do Ribeira, southeastern of São Paulo State, Brazil (Figure 1). In this region, the predominant vegetation types are "Tropical Atlantic Forest Lowland, Submontane and Montane" which belong to the Atlantic Rainforest domain (IBGE, 2012); climate is characterized as warm and humid, with temperatures ranging from $18^{\circ} \mathrm{C}$ to $22^{\circ} \mathrm{C}$ (Barroso et al., 2010) and annual average precipitation is approximately $1500 \mathrm{~mm}$ (Gonçalves et al., 2000). In the PA soil type is mainly Alic Cambisol and in the NPA "GleizadoTiomorfico" (Dalmas, 2013).

The PA (24 $20^{\prime}$ to $24^{\circ} 46^{\prime} \mathrm{S}, 48^{\circ} 03^{\prime}$ to $\left.48^{\circ} 40^{\prime} \mathrm{W}\right)$ comprises Caverna do Diabo State Park (corresponding to category II of IUCN) with 40,000 hectares of total area and Quilombos do Médio Ribeira Environmental Protection Area (corresponding to category V of IUCN) 


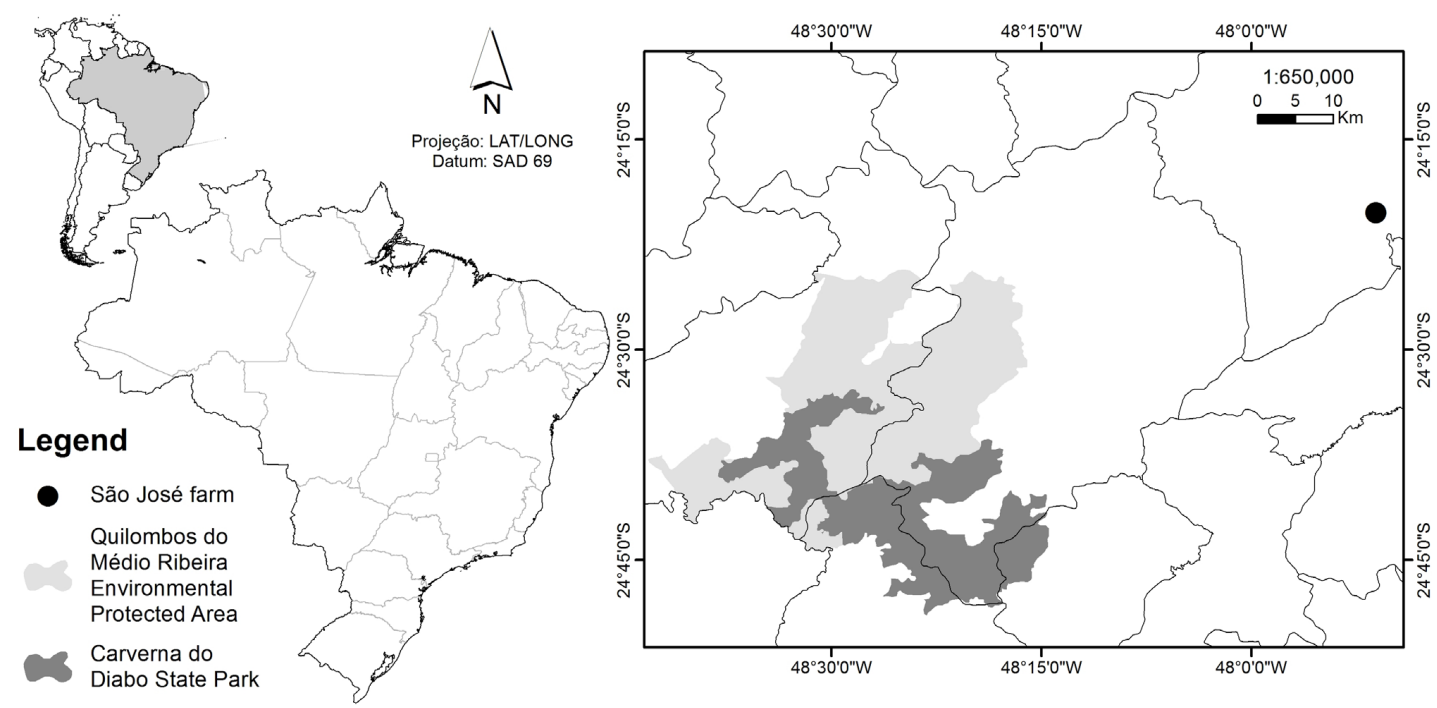

Figure 1. Location of the study areas in São Paulo State, Brazil. Protected area: PA - Caverna do Diabo State Park and Quilombos do Médio Ribeira Environmental Protected Area (dark and light gray); Non-protected area: NPA - São José Farm, Sete Barras, SP (black dot).

with 65,000 hectares of total area. These areas are mostly covered by continuous forests.

NPA- São José Farm (24²0'1.74" S and 47 51'31.66”'W) - has 995.82 hectares and it is privately owned, not legally protected area. About $80 \%$ of the total area is economically explores with pasture for cattle and buffalos. The remaining area consists of native vegetation. Some remnants are abandoned plantations of Hevea brasiliensis, where native vegetation has regenerated over the past 25 years. In other forest areas there is no direct use by the owner. However, due to the lack of surveillance, there are selective logging and Euterpe edulis (palmito-jussara) harvest for palm heart.

\subsection{Selection of indicators}

In this study we selected two types of indicators, according to Lindenmayer et al. (2000): structure-based biodiversity indicators and conservation status or management indicator species. As structure-based biodiversity indicators we selected lianas and tree ferns, using diameter and height class for assessment, respectively. As conservation status or management indicator species we selected understory species composition. Lianas, tree ferns and understory species seem to be more sensitive to habitat changes than canopy species, considering the following features:

The abundance of lianas may be associated with changes caused by natural or anthropogenic disturbances (Engel et al., 1998; Laurance et al., 2001). Therefore, they may serve as indicators of disturbance (Medeiros and Torezan, 2013). In mature forests, it is expected to find individuals with a diameter greater than $10 \mathrm{~cm}$ (Hora and Soares, 2002). Additionally, abundance of lianas tends to decrease in undisturbed forest (Putz, 1984).

Tree ferns (mainly those belonging to the Cyatheaceae and Dicksoniaceae families) are representative in tropical forests (e.g. Atlantic Rainforest), sometimes reaching the canopy (Schmitt and Windisch, 2006). Their trunks can measure up to $30 \mathrm{~cm}$ in circumference and reach $15 \mathrm{~m}$ in height. Their growth rate is very slow and it has been related to forests successional stage (Schmitt and Windisch, 2012). Consequently, we expected to find more tree ferns with greater diameters and heights in mature forests, because they are positively influenced by higher canopy cover, humidity and lower light exposure found in advanced successional stages. In addition, commercially valuable tree ferns may be missing in some mature forests as a result of harvesting or even poaching (Schmitt and Windisch, 2006).

According to Milledge et al. (1991) an indicator must reflect the effects of a disturbance regime and it can be used to draw efforts to mitigate them. Understory species are involved in community maintenance processes (Guariguata and Ostertag, 2001). Consequently, understanding understory dynamics may provide valuable information regarding ecological integrity (Salles and Schiavini, 2007). Thus, composition of the understory can function as an indicator of the successional stage and guide management actions in a protected area.

\subsection{Data collection}

Data collection was carried out using plots (Müller-Dombois and Ellenberg, 1974). In each study site (PA - Caverna do Diabo State Park and Environmental Protection Area Quilombos do Médio Ribeira; and NPA - São José Farm) seven $20 \times 20 \mathrm{~m}$ plots were randomly allocated. In the center of each plot we allocated one $2 \times 20 \mathrm{~m}$ subplot. The understory was sampled in the subplots, and the lianas and tree ferns were sampled in the plots. All plots in PA were distributed at a minimum distance of $50 \mathrm{~m}$ and a maximum of $400 \mathrm{~m}$ apart from each other, and plots in NPA, at a minimum distance of $50 \mathrm{~m}$ to $200 \mathrm{~m}$ apart. 
The understory vegetation was sampled in the subplot of $2 \times 20 \mathrm{~m}$ and included all woody plants with a height $\geq 150 \mathrm{~cm}$ and a circumference at breast height $(\mathrm{CBH})$ $<15 \mathrm{~cm}$. The specimens were collected in reproductive or vegetative phase and the material was pressed and dried for taxonomic identification. The specimens were later deposited in the SORO herbarium (Thiers, 2015).

In this study, we considered lianas as all climbing plants with woody stem that germinate in the soil, remain rooted throughout their lives and climb a support (Müller-Dombois and Ellenberg, 1974; Simpson, 2006). Lianas were sampled in plots of $20 \times 20 \mathrm{~m}$ by counting all individuals and we measured the DBH (diameter at breast height) of the stem, but we have not performed the botanical identification. Tree ferns were sampled in plots of $20 \times 20 \mathrm{~m}$ by counting all individuals with height greater than one meter, without performing botanical identification. We also measured the total height of the individuals.

\subsection{Data analysis}

An environmental characterization of the plots was carried out measuring the following parameters: light, canopy cover, relative humidity, and height of the litter layer. Those variables were chosen because they influence forest structure and understory composition (Medeiros and Torezan, 2013; Cardoso-Leite et al., 2013). Twenty measurements for each variable were taken at sampling points randomly assigned within each of the $20 \times 20 \mathrm{~m}$ plots. The depth of the litter layer was measured with a $30 \mathrm{~cm}$ ruler, perpendicular to the ground surface; luminosity and relative humidity were measured in the morning to avoid bias, with the thermo-hydro anemometer Termohigro Digital Lutron LM-8000 (Suganuma et al., 2008). Measures were always taken when the values were stabilized. Canopy cover was measured with a canopy densiometer (Lemmon, 1957).

We also characterized the plots according to the successional stage using resolution CONAMA 1/94 (Brasil, 1994), a Brazilian national legislation that defines the concept of successional stages in the Atlantic Rainforest domain. The CONAMA resolution is based on Budowski (1965) and it considers: (1) early successional stage - canopy cover ranging from open to closed, species from $1.5 \mathrm{~m}$ to $8.0 \mathrm{~m}$ high, diameter at breast height - DBH - $(130 \mathrm{~cm}$ above the ground) up to $10 \mathrm{~cm}$ and low plant species richness (approximately 10 species); (2) intermediate successional stage - presence of strata at different heights, the upper stratum may have emergent trees, species from 4 to $12 \mathrm{~m}$ high, DBH up to $20 \mathrm{~cm}$ and significant plant richness (among 11 to 30 species), and might have dominance of some species; (3) advanced successional stage - large number of strata, with trees, shrubs, herbs, vines, epiphytes, etc., the upper canopy is generally horizontally wide, with maximum heights exceeding $10 \mathrm{~m}$, average DBH is always greater than $20 \mathrm{~cm}$ and high plant species richness (more than 30 species).

Hereafter the plots are called: U-PA: undisturbed plots within protected area (advanced successional stage); D-PA: disturbed plots within protected area (early successional stage); and ID-NPA: intermediate disturbance plots outside protected area (intermediate successional stage).

The tree ferns and lianas measured within the plots were divided into height and diameter classes, respectively, using the Sturges' Rule (Vieira, 1991). As a result, tree ferns were distributed into five classes of height, each of them with an amplitude of $3.1 \mathrm{~cm}$ while the lianas were distributed into 11 classes of DBH, each with an amplitude of $1.3 \mathrm{~cm}$. Tree ferns height classes were: class $1: 1 \mathrm{~m}$ to $<4.1 \mathrm{~m}$; class 2: $4.1 \mathrm{~m}$ to $<7.2 \mathrm{~m}$; class $3: 7.2 \mathrm{~m}$ to $<10.3 \mathrm{~m}$; class $4: 10.3$ to $<13.4 \mathrm{~m}$; class $5: 13.4 \mathrm{~m}$ to $<16.5 \mathrm{~m}$; class 6: $16.5 \mathrm{~m}$ to $19.6 \mathrm{~m}$; class $7:>19.6 \mathrm{~m}$. Lianas DBH classes were: class $1: 0.1 \mathrm{~cm}$ to $<1.4 \mathrm{~cm}$; class $2: 1.4 \mathrm{~cm}$ to $<2.7 \mathrm{~cm}$; class $3: 2.7 \mathrm{~cm}$ to $<4.0 \mathrm{~cm}$; class $4: 4.0 \mathrm{~cm}$ to $<5.3 \mathrm{~cm}$; class 5: $5.3 \mathrm{~cm}$ to $<6.6 \mathrm{~cm}$; class $6: 6.6 \mathrm{~cm}$ to $<7.9 \mathrm{~cm}$; class 7: $7.9 \mathrm{~cm}$ to $<9.2 \mathrm{~cm}$; class $8: 9.2 \mathrm{~cm}$ to $<10.5 \mathrm{~cm}$; class 9: $10.5 \mathrm{~cm}$ to $<11.8 \mathrm{~cm}$; class $10: 11.8$ to $<13.1 \mathrm{~cm}$; class 11: $>13.1 \mathrm{~cm}$.

We performed a Canonical Correspondence Analysis - CCA (Borcard et al., 2011) (ANOVA permutation test, using 999 random permutations) in order to analyze relationships among understory species (filter to five individual, or more, per species), tree fern height classes, lianas DBH classes, studied areas, and the environmental characterization (Table 1). We also analyzed understory species using IndVal method (Dufrene and Legendre, 1997), which examines the relationship between species occurrence from the sampled sites, and according to classification of these sites considering characteristics of these areas (Dufrene and Legendre, 1997). In this study, we grouped our sampled areas by their successional stages. We expected to find more tree ferns with greater heights and lianas with greater diameters in undisturbed forests. To check that, ANOVA and Tukey's test were performed to compare the average height of tree ferns and average DBH of lianas. All the analyses were performed using R "vegan" and "indicspecies" packages (R Core Team, 2014).

\section{Results}

The majority of plots in PA (1, 2, 3, 5, 6 and 7) were classified as advanced successional stage, except plot 4, which that was classified as in early successional stage. All plots allocated in NPA were classified as intermediate successional stage.

In PA's understory, we sampled 195 individuals belonging to 75 species, 46 genera and 28 families. In NPA, 238 individuals belonging to 75 species, 44 genera and 31 families were sampled (Appendix A). From the total number of species sampled in both areas, 25 were sampled with more than five individuals, including the dead individuals, considered as one species. Considering IndVal analysis, Bathysa australis (Figure 2A) was considered an indicator of undisturbed areas (U-PA) $(\mathrm{p}<0.001$; IndVal=1), Piper arboreum (Figure 2B) was considered an indicator of disturbed areas (D-PA) $(\mathrm{p}<0.05$; IndVal $=0.837)$, and none of the species could be related to intermediate disturbance areas (ID-NPA). 
Table 1. Environmental characteristics of the studied sites: undisturbed protected area (U-PA) and intermediately disturbed non-protected area (ID-NPA).

\begin{tabular}{lcccc}
\hline Plots & Litter layer $(\mathbf{c m})$ & Canopy cover (\%) & Light (lux) & Humidity (\%) \\
\hline U-PA (1) & 6.9 & 99.5 & 252.04 & 72.3 \\
U-PA (2) & 4.8 & 99.9 & 526.6 & 68.11 \\
U-PA (3) & 6.2 & 99.3 & 626.8 & 69.2 \\
D-PA (4) & 7 & 99.6 & 1149.2 & 68.8 \\
U-PA (5) & 7.9 & 99.9 & 3309.9 & 64.2 \\
U-PA (6) & 5.2 & 100 & 256.9 & 66.6 \\
U-PA (7) & 7.6 & 99.6 & 663.8 & 64.2 \\
ID-NPA (8) & 3.1 & 99 & 272.6 & 78.6 \\
ID-NPA (9) & 4 & 99.6 & 166.3 & 73.6 \\
ID-NPA (10) & 3.2 & 99.1 & 484.9 & 75.1 \\
ID-NPA (11) & 3.5 & 98 & 1050.4 & 72 \\
ID-NPA (12) & 3.6 & 99.4 & 452.6 & 74.1 \\
ID-NPA (13) & 2.85 & 99.5 & 340.9 & 70.1 \\
ID-NPA (14) & 3.3 & 99.4 & 285.5 & 71.6 \\
\hline
\end{tabular}

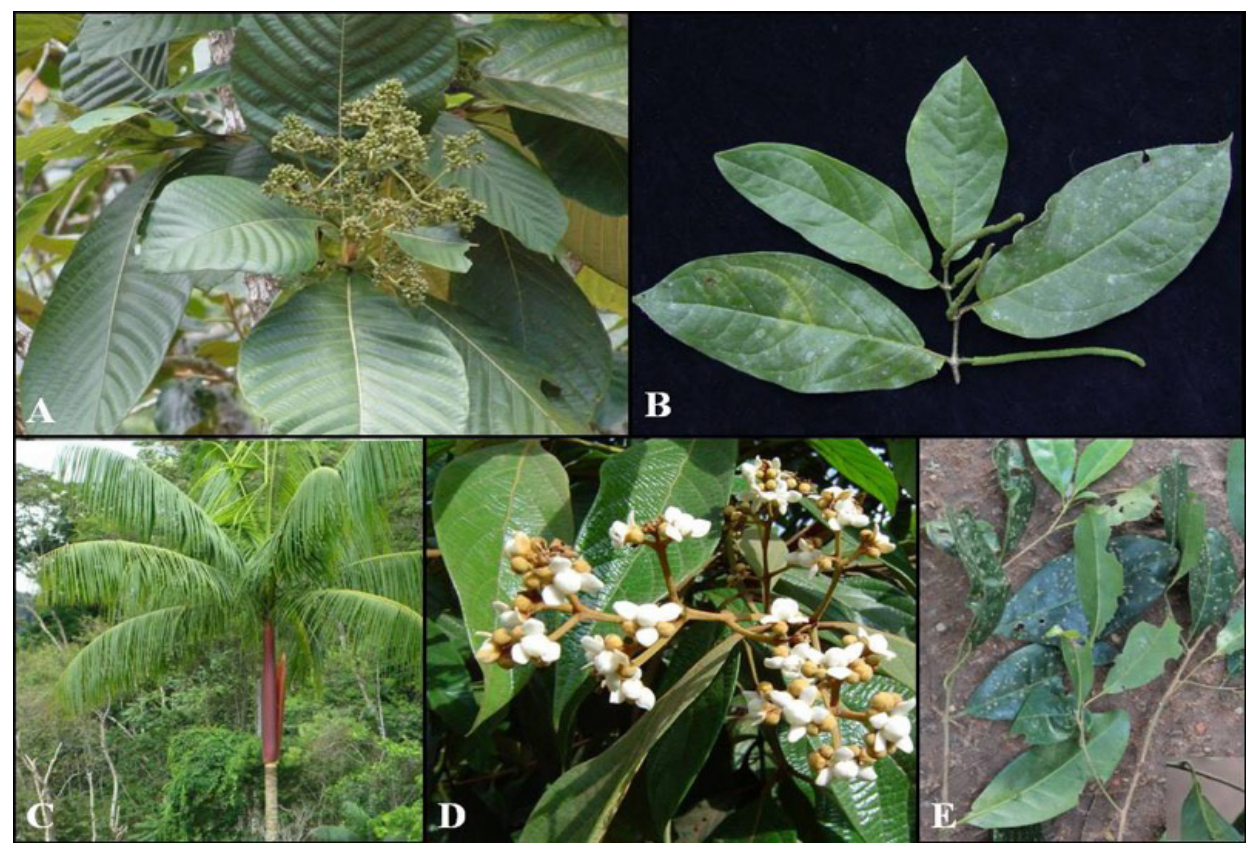

Figure 2. Species considered indicators in the two sites studied (undisturbed protected area (U-PA) and intermediately disturbed non-protected area (ID-NPA): (A) Bathysa australis (A.St.-Hil.) K.Schum. (Photo: Eugênio A. Melo); (B) Piper arboreum Aubl. (Photo: Rolando Perez); (C) Euterpe edulis Mart. (Photo: Eugênio A. Melo); (D) Nectandra oppositifolia Nees (Photo: Eugênio A. Melo); (E) Pera glabrata (Schott) Poepp. ex Baill. (Photo: Ana C.D. Castello).

Tree ferns in NPA were not found in four of the seven plots and height average in D-PA was $6.7 \mathrm{~m}$, in ID-NPA was $2.2 \mathrm{~m} \pm 1.16$ and in U-PA was $10.54 \mathrm{~m} \pm 5.47$ (Figure 3). We found significant differences $(p<0.01)$ between ID-NPA and U-PA, but not between D-PA and ID-NPA $(p=0.362)$ and D-PA and U-PA $(p=0.628)$. D-PA was represented only by one plot and that might be the reason there were no differences between D-PA and the other successional stages (ID-PA and U-PA). Lianas were sampled in all plots and the DBH average in D-PA was $1.0 \mathrm{~cm}$, in ID-NPA was
$1.5 \mathrm{~cm} \pm 0.37$ and in U-PA was $1.4 \mathrm{~cm} \pm 0.47$ (Figure 4). There were no significant differences $(p=0.346)$ in the $\mathrm{DBH}$ average of the lianas among the successional stages (D-PA, ID-NPA and U-PA).

Only one axis of CCA was significant (axis $1=p<0.001$; axis $2=p>0.1$ ), and explained $18.11 \%$ of the total variation in species composition (Figure 5). Two groupsformed: group 1 - all plots from PA except 1, all tree ferns height classes except class 1, liana DBH class 11, light, canopy cover, litter cover, and species Allophylus edulis, Bathysa 


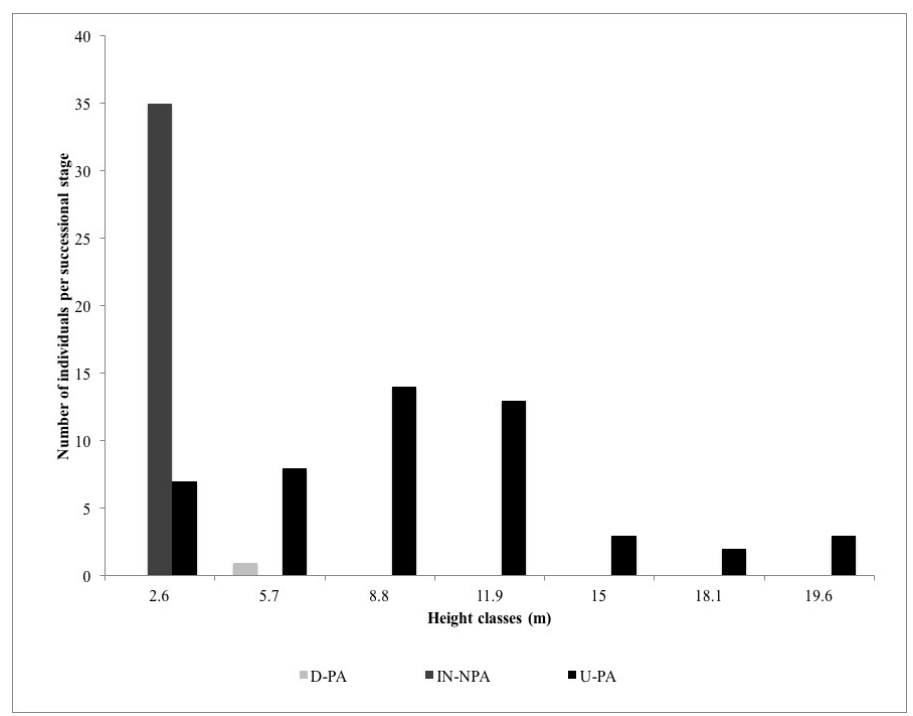

Figure 3. Abundance of tree ferns in height classes sampled in the two sites studied - undisturbed protected area (U-PA) and intermediately disturbed non-protected area (ID-NPA) - in Vale do Ribeira region in Atlantic rainforest domain. D-PA: disturbed plots within protected area (early successional stage); ID-NPA: intermediate disturbance plots outside protected area (intermediate successional stage); and U-PA: undisturbed plots within protected area (advanced successional stage).

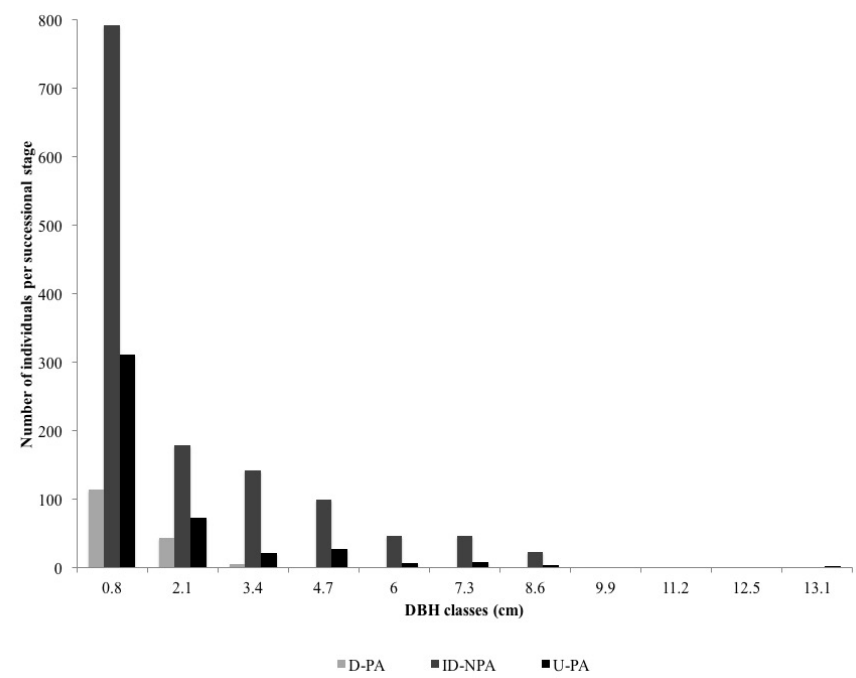

Figure 4. Abundance of lianas in diameter at breast height (DBH) classes sampled in the two sites studied - undisturbed protected area (U-PA) and intermediately disturbed non-protected area (ID-NPA) - in Vale do Ribeira region in Atlantic rainforest domain. D-PA: disturbed plots within protected area (early successional stage); and ID-NPA: intermediate disturbance plots outside protected area (intermediate successional stage).

australis, Bactris sp., Dahlstedtia pinnata, Euterpe edulis, Guapira opposita, Mollinedia schottiana, Nectandra leucantha, Ocotea teleiandra and Piper gaudichaudianum; group 2-PA's plot 1, all plots from NPA, tree fern height class 1 , all the remaining liana DBH classes, humidity and species Cabralea canjerana, Eugenia florida, Guarea macrophylla, Guatteria australis, Hevea brasiliensis, Eugenia cuprea, Myrcia spectabilis, Nectandra oppositifolia,
Ouratea parviflora, Rubiaceae sp.3, Rubiaceae sp.5, Pera glabrata, Psychotria leiocarpa, Psychotria cf. suterella and Virola gardneri. We found significant differences ( $p<0.001 ; F=21.84)$ in litter cover between U-PA and ID-NPA and D-PA and ID-NPA, with the highest values found in U-PA and D-PA (Table 1). Humidity was also significantly different $(\mathrm{p}<0.01 ; \mathrm{F}=7.27)$ between U-PA and ID-NPA, with the highest values found in ID-NPA. 


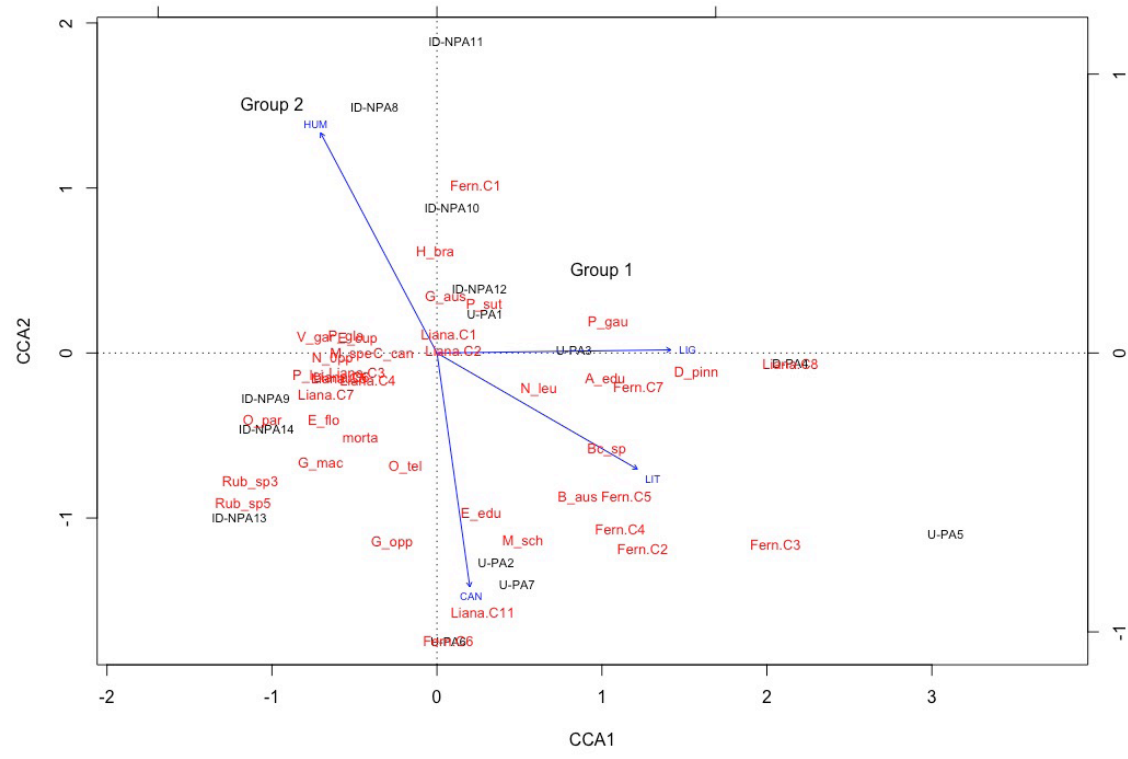

Figure 5. Canonical Correspondence Analysis of the understory species (with more than five individuals), tree ferns and lianas and its association with annual environmental variables sampled in the two sites studied - undisturbed protected area (U-PA) and intermediately disturbed non-protected area (ID-NPA) - in Vale do Ribeira region in Atlantic rainforest domain CAN: canopy cover; HUM: humidity; LIT: litter cover; LIG: light. A_edu = Allophylu sedulis; Bc_sp. = Bactris sp.; B_aus = Bathysa australis $;$ C_can $=$ Cabralea canjerana $; \mathrm{D} \_$pinn $=$Dahlstedtia pinnata $;$E_cup $=$Eugenia cuprea ; $\mathrm{E} \_$flo $=$Eugeniaflorida $; \mathrm{E} \_$edu $=$Euterpe edulis $; \mathrm{G} \_$opp $=$Guapiraopposita $; \mathrm{G} \_\mathrm{mac}=$ Guarea macrophylla $; \mathrm{G}$ _aus $=$ Guatteria australis; H_bra = Hevea brasiliensis; M_sch = Mollinedia schottiana; "morta" = Deadtrees; M_spe = Myrcia spectabilis; N_leu = Nectandra leucantha $;$ N_opp = Nectandra oppositifolia $;$ O_tel = Ocotea teleiandra $;$ O_par = Ouratea parviflora; P_gla = Pera glabrata $;$ P_gau = Piper gaudichaudianum $;$ P_sut $=$ Psychotria cf. suterella $;$ P_lei $=$ Psychotria leiocarpa; Rub_sp3 = Rubiaceaesp.3; Rub_sp5 = Rubiaceae sp.5; V_gar = Virola gardneri.

Canopy cover $(\mathrm{p}=0.177 ; \mathrm{F}=2.627)$ and light $(\mathrm{p}=0.488$; $\mathrm{F}=0.766)$ showed no significant differences.

\section{Discussion}

Our study identified indicator species of (i) disturbed areas, (e.g., Piper arboreum Aubl.); (ii) intermediated disturbed areas, (e.g., Nectandra oppositifolia Nees (Figure 2D) and Pera glabrata (Schott) Poepp.); and (iii) undisturbed areas (e.g., Bathysa australis (A.St.-Hil.) K.Schum and Euterpe edulis Mart.). These species and the large lianas and tree ferns can be useful tools to monitor protected areas in the Atlantic rainforest.

Nutrient cycling, productivity and ecosystem stability differ according to the degree of forest maturity. Species require particular conditions for development, such as pioneer species that depend on light to germinate and grow (Swaine and Whitmore, 1988) leading to poor establishment in late succession stages (van Breugel et al., 2013). Shade tolerant species can germinate and grow under forest shade (Swaine and Whitmore, 1988), consequently found mainly in late successional stages (Liebsch et al., 2008). Besides species successional groups, structural features also relates to forest conditions, as pointed out in our study.

Bathys a australis - a shade tolerant species - is usually recorded among those with the highest importance value in undisturbed areas (Guilherme et al., 2004; Cardoso-Leite et al., 2013) or areas where disturbance occurred in the past, but with shaded understory (Bosa et al., 2015). Euterpe edulis (Figure 2C) is a shade tolerant species, typically occurring in undisturbed forest (Aidar et al., 2001; Moreno et al., 2003). E. edulis plays an important role in forest succession because it is an abundant species and has a strong interaction with fauna (Reis and Kageyama, 2000); produces large number of flowers and fruits, which serve as food source for insects, birds and mammals (Reis and Kageyama, 2000). Pioneer species such as Piper arboreum (Figure 2B), Nectandra oppositifolia (Figure 2D) and Pera glabrata (Figure 2E) plays an important role in forest regeneration (Denslow, 1980), because they establish in forests gaps (Tabarelli and Mantovani, 1999) and also facilitate establishment of other species during successional advancement (Connell and Slatyer, 1977).

Despite no differences in lianas DBH average, almost all lianas DBH classes were related to the ID-NPA plots and only the largest liana DBH class (class 11) was related to U-PA plots. The same pattern was observed by Letcher and Chazdon (2009) in vegetation areas, in different successional stages, and found an increase in the mean diameter of lianas according to forest ageing, i.e., with successional advancement. In early successional stages 
it is common to find higher abundance of lianas with smaller diameters (Dewalt et al., 2000; Medeiros and Torezan, 2013). Carvalho et al. (2011) highlighted that, usually, lianas with large diameters are found mostly in areas with low levels of disturbance.

Our study showed that disturbance conditions seem to influence tree fern growth. This pattern was already found in the literature (Bittner and Breckle, 1995; Arens and Sánchez-Baracaldo, 1998), but the relationship between height growth in different levels of disturbance and/or successional stages was not found in the literature. Instead, Bittner and Breckle (1995) and Schmitt and Windisch (2012) highlighted that trunk growth in secondary forest is three times faster than in primary forest. On the other hand, disturbance can affected richness and abundance of ferns (Silva et al., 2011), as observed ID-NPA, with low density of tree ferns in this area.

Environmental variables influenced the formation of groups in CCA, and plots of PA, in most cases, there are the highest values of litter and canopy cover. Litter cover plays an important role in nutrient cycling because it is the nutrient source that accumulates in the soil (Regina, 2001), and it protects soil from erosion. Late successional stages have larger, well-developed canopy than early successional stages, which leads to deeper litter cover (Vidal et al., 2007). Canopy cover, luminosity and litter cover associates with each other, influencing species establishment and growth (Denslow, 1980). Higher canopy cover leads to low light availability and high litter production, favoring shade tolerant species. Medeiros and Torezan (2013), studying fragments of Seasonal Semideciduous Forest found a positive relationship between canopy cover and ecological integrity.

\section{Conclusions}

Indicator species, pointed out in this study, can be useful in monitoring programs and protocol development for long-term monitoring, in order to meet conservation objectives of protected areas, mainly because indicator species are easy to identify. For instance, the presence of indicator species of disturbed forest (e.g. Piper arboretum, Nectandra oppositifolia and Pera glabrata) and the absence of indicators of undisturbed forest (e.g. Bathysa australis, Euterpe edulis, large lianas and tree ferns) can be used as an alert that the area has suffered degradation. Lianas of larger diameter (above $13 \mathrm{~cm}$ ) and tall tree ferns (above $4.1 \mathrm{~m}$ ) can also be used as indicators of well conserved vegetation. All these information should support management practices and impact mitigation practices. Further studies are needed to clarify if the species selected in our study as indicator species of successional stages and conservation status can be replicable in other areas and vegetation types.

\section{Acknowledgements}

The authors are thankful to Universidade Federal de São Carlos, Capes and Sete Barras Project (FAI-UFSCar) for the financial support; Salvador Gezan and Fernando Rodrigues da Silva for the assistance with statistical analysis; Larissa Campos and Alice Martinez for the field work assistance; Eric Kataoka for the English review; Eugênio A. Melo and Rolando Perez for granting the photographs of indicator species; Fundação Florestal de São Paulo; the staff of Caverna do Diabo State Park and Quilombos do Médio Ribeira Environmental Protected Area for allowing us to conduct this research, and to the anonymous reviewers for the invaluable comments, which greatly improved the manuscript.

\section{References}

AIDAR, M.P.M., GODOY, J.R.L., BERGMANN, J. and JOLY, C.A., 2001. Atlantic Forest succession over calcareous soil, Parque Estadual Turístico do Alto da Ribeira - PETAR, SP. Brazilian Journal of Botany, vol. 24, no. 4, pp. 455-469. http://dx.doi. org/10.1590/S0100-84042001000400012.

ARENS, N.C. and SÁNCHEZ-BARACALDO, P., 1998. Distribution of tree ferns (Cyatheaceae) across the successional mosaic in an Andean cloud forest, Nariño, Colombia. American Fern Journal, vol. 88, no. 2, pp. 60-71. http://dx.doi.org/10.2307/1547225.

BARROSO, R.M., REIS, A. and HANAZAKI, N., 2010. Etnoecologia e etnobotânica da palmeira juçara (Euterpe edulis Martius) em comunidades quilombolas do Vale do Ribeira, São Paulo. Acta Botanica Brasílica, vol. 24, no. 2, pp. 518-528. http:// dx.doi.org/10.1590/S0102-33062010000200022.

BITTNER, J. and BRECKLE, S.W., 1995. The growth rate and age of tree fern trunks in relation to habitats. American Fern Journal, vol. 85, no. 2, pp. 37-42. http://dx.doi.org/10.2307/1547463.

BORCARD, D., GILLET, F. and LEGENDRE, P., 2011. Numerical ecology with R. New York: Springer. 306 p. http:// dx.doi.org/10.1007/978-1-4419-7976-6.

BOSA, D.M., PACHECO, D., PASETTO, M.R. and SANTOS, R., 2015. Florística e estrutura do componente arbóreo de uma Floresta Ombrófila Densa Montana em Santa Catarina, Brasil. Revista Árvore, vol. 39, no. 1, pp. 49-58. http://dx.doi. org/10.1590/0100-67622015000100005.

BRASIL. Conselho Nacional do Meio Ambiente-CONAMA, 1994. Resolução no. 1/1994. Define vegetação primária e secundária nos estágios pioneiro, inicial e avançado de regeneração da Mata Atlântica, afim de orientar os procedimentos de licenciamento de exploração da vegetação nativa no Estado de São Paulo. Diário Oficial da União, Brasília, 3 fev. Seção 1.

BUDOWSKI, A., 1965. Distribution of tropical American rain forest species in the light of successional progresses. Turrialba, vol. 15 , no. 1 , pp. $40-42$.

BUTCHART, S.H., WALPOLE, M., COLLEN, B., VAN STRIEN, A., SCHARLEMANN, J.P., ALMOND, R.E., BAILLIE, J.E., BOMHARD, B., BROWN, C., BRUNO, J., CARPENTER, K.E., CARR, G.M., CHANSON, J., CHENERY, A.M., CSIRKE, J., DAVIDSON, N.C., DENTENER, F., FOSTER, M., GALLI, A., GALLOWAY, J.N., GENOVESI, P., GREGORY, R.D., HOCKINGS, M., KAPOS, V., LAMARQUE, J.F., LEVERINGTON, F., LOH, J., MCGEOCH, M.A., MCRAE, L., MINASYAN, A., HERNÁNDEZ MORCILLO, M., OLDFIELD, T.E., PAULY, D., QUADER, S., REVENGA, C., SAUER, J.R., SKOLNIK, B., SPEAR, D., STANWELL-SMITH, D., STUART, S.N., SYMES, 
A., TIERNEY, M., TYRRELL, T.D., VIÉ, J.C. and WATSON, R., 2010. Global biodiversity: indicators of recent declines. Science, vol. 328, no. 5982, pp. 1164-1168. http://dx.doi.org/10.1126/ science.1187512. PMid:20430971.

CARDOSO-LEITE, E., PODADERA, D.S., PERES, J.C. and CASTELLO, A.C.D., 2013. Analysis of floristic composition and structure as an aid to monitoring protected areas of dense rain forest in southeastern Brazil. Acta Botanica Brasílica, vol. 27, no. 1, pp. 180-194. http://dx.doi.org/10.1590/S0102-33062013000100018.

CARIGNAN, V. and VILLARD, M.A., 2002. Selecting indicator species to monitor ecological integrity: a review. Environmental Monitoring and Assessment, vol. 78, no. 1, pp. 45-61. http://dx.doi. org/10.1023/A:1016136723584. PMid:12197640.

CARVALHO, P.G., MELLIS, J., ASCENÇÃO, B.M., CESTARI, F.M., ALVES, L.F. and GROMBONE-GUARATINI, M.T., 2011. Abundância e biomassa de lianas em um fragmento de floresta Atlântica. Hoehnea, vol. 38, no. 2, pp. 307-314. http://dx.doi. org/10.1590/S2236-89062011000200010.

CONNELL, J.H. and SLATYER, R.O., 1977. Mechanisms of succession in natural communities and their role in community stability and organization. American Naturalist, vol. 111, no. 982, pp. 1119-1144. http://dx.doi.org/10.1086/283241.

CONNELL, J.H., 1978. Diversity in tropical rain forests and coral reefs. Science, vol. 199, no. 24, pp. 1302-1310. http://dx.doi. org/10.1126/science.199.4335.1302. PMid:17840770.

DALMAS, F.B., 2013. Análise da evolução do uso e ocupação do solo na UGRHI-11 e avaliação de cenários futuros em função de processos erosivo e de movimentos de massa utilizando técnicas de geoprocessamento. São Paulo: Instituto de Geociências, Universidade de São Paulo, 144 p. PhD Thesis.

DENSLOW, J.S., 1980. Gap partioning among tropical rain forest trees. Biotropica, vol. 12, no. 2, suppl., pp. 47-55. http://dx.doi. org/10.2307/2388156.

DENSLOW, J.S., 1987. Tropical rain forest gaps and tree species diversity. Annual Review of Ecology Evolution and Systematics, vol. 18, no. 1, pp. 431-451. http://dx.doi.org/10.1146/annurev. es.18.110187.002243.

DEWALT, S.J., SCHNITZER, S.A. and DENSLOW, J.S., 2000. Density and diversity of lianas along a chronosequence in a central Panamanian tropical forest. Journal of Tropical Ecology, vol. 16, no. 1, pp. 1-19. http://dx.doi.org/10.1017/S0266467400001231.

DUELLI, P. and OBRIST, M.K., 2003. Biodiversity indicators: the choice of values and measures. Agriculture, Ecosystems \& Environment, vol. 98, no. 1-3, pp. 87-98. http://dx.doi.org/10.1016/ S0167-8809(03)00072-0.

DUFRENE, M. and LEGENDRE, P., 1997. Species assemblages and indicators species: the need for a flexible asymmetrical approach. Ecological Monographs, vol. 67, no. 3, pp. 345-366.

ENGEL, V.L., FONSECA, R.C.B. and OLIVEIRA, R.E., 1998. Ecologia de lianas e o manejo de fragmentos florestais. Série Técnica IPEF, vol. 12, no. 32, pp. 43-64.

GARDNER, T., 2010. Monitoring biodiversity in certified forests. ETFRN News, vol. 51, pp. 27-33.

GASTON, K.J., CHARMAN, K., JACKSON, S.F., ARMSWORTH, P.R., BONN, A., BRIERS, R.A., CALLAGHAN, C.S.Q., CATCHPOLE, R., HOPKINS, J., KUNIN, W.E., LATHAM, J., OPDAM, P., STONEMAN, R., STROUD, D.A. and TRATT, R., 2006. The ecological effectiveness of protected areas: the United
Kingdom. Biological Conservation, vol. 132, no. 1, pp. 76-87. http://dx.doi.org/10.1016/j.biocon.2006.03.013.

GONÇALVES, P.S., SAES, L.A., FURTADO, E.L., SAMBUGARO, R. and SAKAI, M., 2000. Clones promissores de seringueira para a região do Vale do Ribeira, São Paulo. Pesquisa Agropecuária Brasileira, vol. 35, no. 12, pp. 2343-2353. http://dx.doi.org/10.1590/ S0100-204X2000001200004.

GUARIGUATA, M.R. and OSTERTAG, R., 2001. Neotropical secondary forest succession: changes in structural and functional characteristics. Forest Ecology and Management, vol. 148, no. 1-3, pp. 185-206. http://dx.doi.org/10.1016/S0378-1127(00)00535-1.

GUILHERME, F.A.G., MORELLATO, L.P.C. and ASSIS, M.A., 2004. Horizontal and vertical tree community structure in lowland Atlantic Rain Forest, Southeastern Brazil. Brazilian Journal of Botany, vol. 27, no. 4, pp. 725-737. http://dx.doi.org/10.1590/ S0100-84042004000400012.

HORA, R.C. and SOARES, J.J., 2002. Estrutura fitossociológica da comunidade de lianas em uma floresta estacional semidecidual na Fazenda Canchim, São Carlos, SP. Brazilian Journal of Botany, vol. 25, no. 3, pp. 323-329. http://dx.doi.org/10.1590/ S0100-84042002000300008.

INSTITUTO BRASILEIRO DE GEOGRAFIA E ESTATÍSTICA - IBGE, 2012. Manual técnico da vegetação brasileira. Rio de Janeiro: IBGE. 272 p.

INSTITUTO CHICO MENDES DE CONSERVAÇÃO DA BIODIVERSIDADE - ICMBio. World Wide Fund for NatureBrazil - WWF-Brazil, 2011. Avaliação comparada das aplicações do método Rappam nas unidades de conservação federais, nos ciclos 2005-06 e 2010.l. Brasília: ICMBio. 131 p.

KRONKA, F.J.N., NALON, M.A., MATSUKUMA, C.K., KANASHIRO, M.M., YWANE, M.S.S., PAVÃO, M., DURIGAN, G., LIMA, L.M.P.R., GUILLAUMON, J.R., BAITELLO, J.B., BORGO, S.C., MANETTI, L.A., BARRADAS, A.M.F., FUKUDA, J.C., SHIDA, C.N., MONTEIRO, C.H.B., PONTINHA, A.A.S., ANDRADE, G.G., BARBOSA, O., SOARES, A.P., COUTO, H.T.Z. and JOLY, C.A., 2005. Inventário florestal da vegetação natural do Estado de São Paulo. São Paulo: Imprensa Oficial. 200 p.

LAURANCE, W.F., PÉREZ-SALICRUP, D., DELAMÔNICA, P., FEARNSIDE, P.M., D'ANGELO, S., JEROZOLINSKI, A., POHL, L. and LOVEJOY, T.E., 2001. Rain forest fragmentation and the structure of Amazonian liana communities. Ecology, vol. 82, no. 1, pp. 105-116. http://dx.doi.org/10.1890/00129658(2001)082[0105:RFFATS]2.0.CO;2.

LE SAOUT, S., HOFFMANN, M., SHI, Y., HUGHES, A., BERNARD, C., BROOKS, T.M., BERTZKY, B., BUTCHART, S.H.M., STUART, S.N., BADMAN, T. and RODRIGUES, A.S.L., 2013. Protected areas and effective biodiversity conservation. Science, vol. 342, no. 6160, pp. 803-805. http://dx.doi.org/10.1126/ science.1239268. PMid:24233709.

LEMMON, P.E., 1957. A new instrument for measuring forest overstory density. Journal of Forestry, vol. 55, no. 9, pp. 667-668.

LETCHER, S.G. and CHAZDON, R.L., 2009. Lianas and selfsupporting plants during tropical forest succession. Forest Ecology and Management, vol. 257, no. 10, pp. 2150-2156. http://dx.doi. org/10.1016/j.foreco.2009.02.028.

LIEBSCH, D., MARQUES, M.C.M. and GOLDENBERG, R., 2008. How long does the Atlantic Rain Forest take to recover after a disturbance? Changes in species composition and ecological features during secondary succession. Biological Conservation, 
vol. 141 , no. 6 , pp. 1717-1725. http://dx.doi.org/10.1016/j. biocon.2008.04.013.

LINDENMAYER, D.B., MARGULES, C.R. and BOTKIN, D.B., 2000. Indicators of biodiversity for ecologically susteinable forest managment. Conservation Biology, vol. 14, no. 4, pp. 941-950. http://dx.doi.org/10.1046/j.1523-1739.2000.98533.x.

MCGEOCH, M.A., 1998. The selection, testing and application of terrestrial insects as bioindicators. Biological Reviews of the Cambridge Philosophical Society, vol. 73, no. 2, pp. 181-201. http://dx.doi.org/10.1017/S000632319700515X.

MEDEIROS, H.R. and TOREZAN, J.M., 2013. Evaluating the ecological integrity of Atlantic forest remnants by using rapid ecological assessment. Environmental Monitoring and Assessment, vol. 185, no. 5, pp. 4373-4382. http://dx.doi.org/10.1007/s10661012-2875-7. PMid:22996823.

MILLEDGE, D.R., PALMER, C.L. and NELSON, J.L., 1991. "Barometers of change": the distribution of large owls and gliders in Mountain Ash forests of the Victorian central highlands and their potential as management indicators. In: D. LUNNEY, ed. Conservation of Australia's forest fauna. Sydney: Royal Zoological Society of New South Wales, pp. 55-65.

MORENO, M.R., NASCIMENTO, M.T. and KURTZ, B.C., 2003. Estrutura e composição florística do estrato arbóreo em duas zonas altitudinais na Mata Atlântica de encosta da região do Imbé, RJ. Acta Botanica Brasílica, vol. 17, no. 3, pp. 371-386. http://dx.doi.org/10.1590/S0102-33062003000300005.

MÜLLER-DOMBOIS, D. and ELLENBERG, H., 1974. Aims and methods of vegetation ecology. New York: Wiley. $547 \mathrm{p}$

MYERS, N., MITTERMEIER, R.A., MITTERMEIER, C.G., FONSECA, G.A.B. and KENT, J., 2000. Biodiversity hotspots for conservation priorities. Nature, vol. 403, no. 6772, pp. 853-858. http://dx.doi.org/10.1038/35002501. PMid:10706275.

NOSS, R.F., 1990. Indicators for monitoring biodiversity: a hierarchical approach. Conservation Biology, vol. 4, no. 4, pp. 355-364. http://dx.doi.org/10.1111/j.1523-1739.1990.tb00309.x.

NOSS, R.F., 1999. Assessing and monitoring forest biodiversity: a suggested framework and indicators. Forest Ecology and Management, vol. 115, no. 2-3, pp. 135-146. http://dx.doi. org/10.1016/S0378-1127(98)00394-6.

PARROTTA, J.A., WILDBURGER, C. and MANSOURIAN, S., 2012. Understanding relationships between biodiversity, carbon, forests and people: the key to achieving REDD+ objectives. Vienna: IUFRO. 161 p. IUFRO World Series.

PEARCE, J.L. and VENIER, L.A., 2006. The use of ground beetles (Coleoptera: Carabidae) and spiders (Araneae) as bioindicators of sustainable forest management: a review. Ecological Indicators, vol. 6, no. 4, pp. 780-793. http://dx.doi. org/10.1016/j.ecolind.2005.03.005.

PUTZ, F.E., 1984. The natural history of lianas on Barro Colorado Island, Panama. Ecology, vol. 65, no. 6, pp. 1713-1724. http:// dx.doi.org/10.2307/1937767.

R CORE TEAM, 2014 [viewed 7 March 2014]. R: a language and environmental for statistical computing [online]. Vienna. Available from: http://www.r-project.org

REGINA, I.S., 2001. Litter fall, decomposition and nutrient release in three semi-arid forests of the Duero basin, Spain. Forestry, vol. 74, no. 4, pp. 347-358. http://dx.doi.org/10.1093/forestry/74.4.347.
REIS, A. and KAGEYAMA, P.Y., 2000. Dispersão de sementes de Euterpe edulis Martius Palmae. Sellowiana, no. 49-52, pp. 60-92.

RIBEIRO, M.C., METZGER, J.P., MARTENSEN, A.C., PONZONI, F.J. and HIROTA, M.M., 2009. The Brazilian Atlantic forest: how much is left, and how is the remaining forest distributed? Implications for conservation. Conservation Biology, vol. 142, no. 6, pp. 1141-1153. http://dx.doi.org/10.1016/j.biocon.2009.02.021.

RODRIGUES, L.A., DE CARVALHO, D.A., OLIVEIRA-FILHO, A.T. and CURI, N., 2007. Efeitos de solos e topografia sobre a distribuição de espécies arbóreas em um fragmento de Floresta Estacional Semidecidual, em Luminárias, MG. Revista Árvore, vol. 31, no. 1, pp. 25-35. http://dx.doi.org/10.1590/S010067622007000100004

SALLES, J.C. and SCHIAVINI, I., 2007. Estrutura e composição do estrato de regeneração em um fragmento florestal urbano: implicações para a dinâmica e a conservação da comunidade arbórea. Acta Botanica Brasílica, vol. 21, no. 1, pp. 223-233. http://dx.doi.org/10.1590/S0102-33062007000100021.

SCHMITT, J.L. and WINDISCH, P.G., 2006. Growth rates and age estimates of Alsophila setosa Kaulf. in Southern Brazil. American Fern Journal, vol. 96, no. 4, pp. 103-111. http://dx.doi. org/10.1640/0002-8444(2006)96[103:GRAAEO]2.0.CO;2.

SCHMITT, J.L. and WINDISCH, P.G., 2012. Caudex growth and phenology of Cyathea atrovirens (Langsd. \& Fisch.) Domin (Cyatheaceae) in secondary forest, southern Brazil. Brazilian Journal of Biology = Revista Brasileira de Biologia, vol. 72, no. 2, pp. 397-405. http://dx.doi.org/10.1590/S1519-69842012000200023. PMid:22735150.

SILVA, I.A.A., PEREIRA, A.F.N. and BARROS, I.C.L., 2011. Edge effects on fern community in an Atlantic Forest remnant of Rio Formoso, PE, Brazil. Brazilian Journal of Biology $=$ Revista Brasileira de Biologia, vol. 71, no. 2, pp. 421-430. http://dx.doi. org/10.1590/S1519-69842011000300011. PMid:21755159.

SIMPSON, M.G., 2006. Plant systematics. San Diego: Elsevier Academic Press. 590 p.

SUGANUMA, M.S., TOREZAN, J.M.D., CAVALHEIRO, A.L., VANZELA, A.L.L. and BENATO, T., 2008. Comparando metodologias para avaliar a cobertura do dossel e a luminosidade no sub-bosque de um reflorestamento e uma floresta madura. Revista Árvore, vol. 32, no. 2, pp. 377-385. http://dx.doi.org/10.1590/ S0100-67622008000200020.

SWAINE, M.D. and WHITMORE, T.C., 1988. On the definition of ecological species groups in tropical rain forest. Vegetatio, vol. 75, no. 1-2, pp. 81-86. http://dx.doi.org/10.1007/BF00044629.

TABARELLI, M. and MANTOVANI, W., 1999. Clareiras naturais e a riqueza de espécies pioneiras em uma Floresta Atlântica Montana. Brazilian Journal of Biology $=$ Revista Brasileira de Biologia, vol. 59, no. 2, pp. 251-261. http://dx.doi.org/10.1590/ S0034-71081999000200009.

TABARELLI, M., MANTOVANI, W. and PERES, C.A., 1999. Effects of habitat fragmentation on plant guild structure in the montane Atlantic Forest of southeastern Brazil. Biological Conservation, vol. 91, no. 2-3, pp. 119-127. http://dx.doi. org/10.1016/S0006-3207(99)00085-3.

TERBORG, J. and DAVENPORT, L., 2002. Monitorando as áreas protegidas. In: J. TERBORG, C.V. SCHAIK, L. DAVENPORT and M. RAO, eds. Tornando os parques eficientes: estratégias para a conservação da natureza nos trópicos. Curitiba: UFPR Press, pp. 426-439. 
THIERS, B., 2015 [viewed 5 May 2015]. Index Herbariorum: a global directory of public herbaria and associated staff [online]. New York: New York Botanical Garden's Virtual Herbarium. Available from: http://sweetgum.nybg.org/ih/

VALE, V.S., SCHIAVINI, I., LOPES, S.F., DIAS NETO, O.C., OLIVEIRA, A.P. and GUSSON, A.E., 2009. Composição florística e estrutura do componente arbóreo em um remanescente primário de floresta estacional semidecidual em Araguari, Minas Gerais, Brasil. Hoehnea, vol. 36, no. 3, pp. 417-429. http://dx.doi. org/10.1590/S2236-89062009000300003.

VAN BREUGEL, M., HALL, J.S., CRAVEN, D., BAILON, M., HERNANDEZ, A., ABBENE, M. and VAN BREUGEL, P., 2013. Succession of ephemeral secondary forests and their limited role for the conservation of floristic diversity in a human-modified tropical landscape. PLoS One, vol. 8, no. 12, pp. e82433. http:// dx.doi.org/10.1371/journal.pone.0082433. PMid:24349283.

VIDAL, M.M., PIVELLO, V.R., MEIRELLES, S.T. and METZGER, J.P., 2007. Produção de serapilheira em floresta Atlântica secundária numa paisagem fragmentada (Ibiúna, SP): importância da borda e tamanho dos fragmentos. Brazilian Journal of Botany, vol. 30, no. 3, pp. 521-532. http://dx.doi.org/10.1590/ S0100-84042007000300016.

VIEIRA, S., 1991. Introdução à Bioestatística. Rio de Janeiro: Campus. 293 p.

WALKER, B. and SALT, D., 2006. Resilience thinking: sustaining ecosystems and people in a changing world. Washington: Island Press. 192 p. 
Appendix A. Species sampled in the understory of PA and NPA in Vale do Ribeira Region in Atlantic rainforest domain (PA: Caverna do Diabo State Park and Quilombos do Médio Ribeira Environmental Protected Area; NPA: São José Farm, Sete Barras, SP).

\begin{tabular}{|c|c|c|c|c|c|}
\hline Family & Species & $\mathbf{A B}$ & SG & $\begin{array}{c}\text { Nind } \\
\text { Area } 1\end{array}$ & $\begin{array}{c}\text { Nind } \\
\text { Area 2 } \\
\end{array}$ \\
\hline Acanthaceae & Aphelandra liboniana Linden ex Hook. & A lib & $\mathrm{U}$ & 4 & \\
\hline \multirow{2}{*}{ Annonaceae } & Annonaceae sp.1 & Ann sp1 & $\mathrm{U}$ & 1 & \\
\hline & Guatteria australis A.St.-Hil. & G aus & ST & 1 & 4 \\
\hline Apocynaceae & Malouetia cestroides (Nees ex Mart.) Müll.Arg. & M ces & $\mathrm{P}$ & 2 & \\
\hline \multirow{2}{*}{ Araliaceae } & Araliaceae sp.1 & Ara sp1 & $\mathrm{U}$ & 1 & \\
\hline & Dendropanax monogynus (Vell.) Seem. & D mon & $\mathrm{P}$ & & 3 \\
\hline \multirow{4}{*}{ Arecaceae } & Astrocaryum aculeatissimum (Uhott) Burret & A acu & ST & & 1 \\
\hline & Bactris sp. & B sp & $\mathrm{U}$ & 5 & 1 \\
\hline & Euterpe edulis Mart. & E edu & ST & 15 & 2 \\
\hline & Geonoma elegans Mart. & G ele & ST & 4 & \\
\hline Boraginaceae & Cordia sellowiana Cham. & C sel & $\mathrm{P}$ & & 1 \\
\hline Cardiopteridaceae & Citronella megaphylla (Miers) R.A.Howard & C meg & $\mathrm{P}$ & 3 & \\
\hline \multirow{3}{*}{ Celastraceae } & Maytenus gonoclada Mart. & M gon & ST & & 2 \\
\hline & Maytenus sp. & M sp. & $\mathrm{U}$ & & 1 \\
\hline & Maytenus evonymoides Reissek & M evo & ST & 2 & \\
\hline Chrysobalanaceae & Parinari excelsa Sabine & P exc & ST & 1 & \\
\hline Clusiaceae & Garcinia gardneriana (Planch. \& Triana) Zappi & G gar & ST & 1 & \\
\hline \multirow{2}{*}{ Elaeocarpaceae } & Sloanea guianensis (Aubl.) Benth. & S gui & ST & & 3 \\
\hline & Sloanea hirsuta (Uhott) Planch. ex Benth. & S hir & ST & 1 & \\
\hline \multirow{6}{*}{ Euphorbiaceae } & Actinostemon concepcionis (Chodat \& Hassl.) Hochr. & A com & ST & 1 & \\
\hline & cf. Sebastiania sp. & cf.S sp & $\mathrm{U}$ & 1 & \\
\hline & Croton sp. & C sp. & $\mathrm{U}$ & 2 & \\
\hline & Hevea brasiliensis (Willd. ex A.Juss.) Müll.Arg. & $\mathrm{H}$ bra & ST & & 6 \\
\hline & Tetrorchidium rubrivenium Poepp. & T rub & $\mathrm{P}$ & & 1 \\
\hline & Euphorbiaceae sp.1 & Eu sp1 & $\mathrm{U}$ & 1 & \\
\hline \multirow{16}{*}{ Fabaceae } & Andira fraxinifolia Benth. & A fra & ST & & 1 \\
\hline & Dahlstedtia pinnata (Benth.) Malme & D pinn & ST & 9 & 3 \\
\hline & Fabaceae sp.1 & Fa sp1 & $\mathrm{U}$ & 3 & \\
\hline & Fabaceae sp.2 & Fa sp2 & $\mathrm{U}$ & 1 & \\
\hline & Fabaceae sp.3 & Fa sp3 & $\mathrm{U}$ & 2 & \\
\hline & Fabaceae sp.4 & Fa sp4 & $\mathrm{U}$ & 1 & \\
\hline & Fabaceae sp.5 & Fa sp5 & $\mathrm{U}$ & 1 & \\
\hline & Fabeceae sp.6 & Fa sp6 & $\mathrm{U}$ & & 1 \\
\hline & Inga marginata Willd. & I mar & $\mathrm{P}$ & 2 & \\
\hline & Inga sp. & I sp & $\mathrm{U}$ & 3 & \\
\hline & Machaerium Uleroxylon Tul. & M Ul & ST & 1 & \\
\hline & Machaerium stipitatum Vogel & M sti & $\mathrm{P}$ & 1 & \\
\hline & Myrocarpus frondosus Allemão & $\mathrm{M}$ fro & ST & 1 & \\
\hline & Piptadenia gonoacantha (Mart.) J.F.Macbr. & P gon & $\mathrm{P}$ & 1 & \\
\hline & Pterocarpus rohrii Vahl & P roh & ST & 1 & \\
\hline & Zollernia ilicifolia (Brongn.) Vogel & Z ili & ST & 1 & \\
\hline \multirow{2}{*}{ Indeterminada } & Indet. 1 & Indet. 1 & $\mathrm{U}$ & 1 & \\
\hline & Indet. 2 & Indet. 2 & $\mathrm{U}$ & 2 & \\
\hline Lacistemataceae & Lacistema lucidum Uhnizl. & L luc & ST & & 2 \\
\hline
\end{tabular}

AB: abbreviation for CCA analysis; SG: successional groups; P: pioneer species; ST: shade tolerant species; U: unclassified; Nind: number of individuals sampled. 
Appendix A. Continued...

\begin{tabular}{|c|c|c|c|c|c|}
\hline Family & Species & $\mathbf{A B}$ & SG & $\begin{array}{c}\text { Nind } \\
\text { Area } 1\end{array}$ & $\begin{array}{c}\text { Nind } \\
\text { Area } 2\end{array}$ \\
\hline \multirow{8}{*}{ Lauraceae } & Endlicheria paniculata (Spreng.) J.F.Macbr. & E pan & ST & & 2 \\
\hline & Nectandra leucantha Nees & $\mathrm{N}$ leu & ST & 5 & \\
\hline & Nectandra oppositifolia Nees & N opp & $\mathrm{P}$ & & 6 \\
\hline & Ocotea dispersa (Nees \& Mart.) Mez & $\mathrm{O}$ dis & ST & & 1 \\
\hline & Ocotea indecora (Uhott) Mez & $\mathrm{O}$ ind & ST & 1 & \\
\hline & Ocotea teleiandra (Meisn.) Mez & O tel & ST & 4 & 4 \\
\hline & Lauraceae sp.1 & La sp1 & $\mathrm{U}$ & 1 & \\
\hline & Lauraceae sp.2 & La sp2 & $\mathrm{U}$ & & 2 \\
\hline Malvaceae & Malvaceae sp.1 & Ma sp1 & $\mathrm{U}$ & 1 & \\
\hline \multirow{8}{*}{ Melastomataceae } & Leandra cf. variabilis Raddi & L var & $\mathrm{P}$ & & 1 \\
\hline & Miconia cabucu Hoehne & M cab & ST & & 1 \\
\hline & Miconia cf. cineraUens Miq. & $M \operatorname{cin}$ & $\mathrm{P}$ & & 2 \\
\hline & Miconia centrodesma Naudin & $M$ cen & ST & 1 & \\
\hline & Miconia cinnamomifolia (DC.) Naudin & $M \operatorname{cin}$ & ST & 1 & 1 \\
\hline & Miconia sp. & M sp. & $\mathrm{U}$ & 2 & \\
\hline & Miconia cf. pusilliflora (DC.) Naudin & M pus & $\mathrm{P}$ & & 4 \\
\hline & Tibouchina mutabilis (Vell.) Cogn. & T mut & $\mathrm{P}$ & & 3 \\
\hline \multirow{5}{*}{ Meliaceae } & Cabralea canjerana (Vell.) Mart. & $\mathrm{C}$ can & ST & 4 & 14 \\
\hline & Guarea macrophylla Vahl & G mac & ST & 3 & 8 \\
\hline & Trichilia catigua A.Juss. & T cat & ST & 1 & \\
\hline & Trichilia clausseni C.DC. & $\mathrm{T}$ cla & ST & 2 & \\
\hline & Trichilia pallens C.DC. & T pal & ST & 3 & \\
\hline \multirow{2}{*}{ Monimiaceae } & Mollinedia oligantha Perkins & M oli & ST & & 1 \\
\hline & Mollinedia Uhottiana (Spreng.) Perkins & M Uh & ST & 6 & 3 \\
\hline \multirow{2}{*}{ Moraceae } & Sorocea boSTlandii (Baill.) W.C.Burger et al. & S bon & ST & & 1 \\
\hline & Sorocea cf. hilarii Gaudich. & S hil & ST & & 1 \\
\hline Mortas & Mortas & & - & 2 & 3 \\
\hline \multirow{24}{*}{ Myrtaceae } & cf. Calyptranthes sp. & $\mathrm{cfC} \mathrm{sp}$ & $\mathrm{U}$ & 1 & \\
\hline & Eugenia cf. bocainensis Mattos & E boc & ST & & 1 \\
\hline & Eugenia brevistyla D.Legrand & E bre & ST & & 1 \\
\hline & Eugenia cuprea (O.Berg) Nied. & E cup & ST & 3 & 22 \\
\hline & Eugenia florida DC. & E flo & ST & & 6 \\
\hline & Eugenia monosperma Vell. & E mon & ST & 1 & 1 \\
\hline & Eugenia sp.2 & $\mathrm{Eu} \mathrm{sp2}$ & $\mathrm{U}$ & 1 & \\
\hline & Myrcia anacardiifolia Gardner & $\mathrm{M}$ ana & ST & & 1 \\
\hline & Myrcia multiflora (Lam.) DC & M mul & ST & & 3 \\
\hline & Myrcia spectabilis DC. & M spe & ST & & 5 \\
\hline & Myrcia tijucensis Kiaersk. & M tij & ST & & 1 \\
\hline & Myrcia sp.2 & M sp2 & $\mathrm{U}$ & 1 & \\
\hline & Myrcia sp.1 & M sp1 & $\mathrm{U}$ & 1 & \\
\hline & Eugenia supraaxillaris Spring & E sup & $\mathrm{ST}$ & & 1 \\
\hline & Eugenia cf. verticillata (Vell.) Angely & E ver & $\mathrm{U}$ & 1 & \\
\hline & Myrceugenia myrcioides (Cambess.) O.Berg & M myr & $\mathrm{U}$ & 1 & \\
\hline & Eugenia sp.1 & E sp1 & $\mathrm{U}$ & 1 & \\
\hline & Psidium cattleianum Sabine & P cat & ST & & 1 \\
\hline & Psidium $\mathrm{sp}$ & $P$ sp & $\mathrm{U}$ & & 1 \\
\hline & Syzygium sp. & Sy sp & $\mathrm{U}$ & & 2 \\
\hline & Myrtaceae sp.1 & My sp1 & $\mathrm{U}$ & & 3 \\
\hline & Myrtaceae sp.2 & My sp2 & $\mathrm{U}$ & & 1 \\
\hline & Myrtaceae sp.3 & My sp3 & $\mathrm{U}$ & & 1 \\
\hline & Myrtaceae sp.4 & My sp4 & $\mathrm{U}$ & & 1 \\
\hline
\end{tabular}

AB: abbreviation for CCA analysis; SG: successional groups; P: pioneer species; ST: shade tolerant species; U: unclassified; Nind: number of individuals sampled. 
Appendix A. Continued...

\begin{tabular}{|c|c|c|c|c|c|}
\hline Family & Species & $\mathbf{A B}$ & SG & $\begin{array}{c}\text { Nind } \\
\text { Area } 1\end{array}$ & $\begin{array}{c}\text { Nind } \\
\text { Area } 2\end{array}$ \\
\hline Myristicaceae & Virola gardneri (A.DC.) Warb. & V gar & ST & & 6 \\
\hline \multirow{2}{*}{ Nyctaginaceae } & Guapira opposita (Vell.) Reitz & G opp & ST & 9 & 6 \\
\hline & Neea Uhwackeana Heimerl & N Uh & $\mathrm{P}$ & 2 & \\
\hline \multirow{2}{*}{ Oleaceae } & cf. Chionanthus filiformis (Vell.) P.S.Green & C fil & ST & 1 & \\
\hline & Heisteria silvianii Uhwacke & H sil & ST & & 1 \\
\hline Ochnaceae & Ouratea parviflora (A.DC.) Baill. & O par & ST & & 8 \\
\hline Peraceae & Pera glabrata (Uhott) Poepp. ex Baill. & P gla & $\mathrm{P}$ & & 11 \\
\hline \multirow{2}{*}{ Piperaceae } & Piper cf. arboreum Aubl. & $\mathrm{P}$ arb & $\mathrm{P}$ & 1 & 3 \\
\hline & Piper gaudichaudianum Kunth & P gau & $\mathrm{P}$ & 25 & 20 \\
\hline Polygonaceae & Coccoloba latifolia Lam. & C lat & ST & & 1 \\
\hline Phyllanthaceae & Hieronyma alchorneoides Allemão & $\mathrm{H}$ alc & ST & & 3 \\
\hline \multirow{2}{*}{ Primulaceae } & Myrsine coriacea (Sw.) R.Br. ex Roem. \& Uhult. & M cor & $\mathrm{P}$ & & 1 \\
\hline & Myrsine umbellata Mart. & M umb & ST & 1 & \\
\hline \multirow{13}{*}{ Rubiaceae } & Bathysa australis (A.St.-Hil.) K.Uhum. & B aus & ST & 6 & \\
\hline & Faramea multiflora A.Rich. ex DC. & F mul & $\mathrm{U}$ & & 1 \\
\hline & Margaritopsis cymuligera (Müll.Arg.) C.M.Taylor & M cym & $\mathrm{ST}$ & & 1 \\
\hline & Psychotria leiocarpa Cham. \& Uhltdl. & P lei & ST & & 5 \\
\hline & Psychotria mapourioides DC. & P map & $\mathrm{ST}$ & 2 & \\
\hline & Psychotria cf. suterella Müll.Arg. & P sut & $\mathrm{ST}$ & 2 & 4 \\
\hline & Rudgea recurva Müll.Arg. & $\mathrm{R}$ rec & $\mathrm{ST}$ & 2 & 2 \\
\hline & Rubiaceae sp.1 & $\mathrm{Ru}$ sp1 & $\mathrm{U}$ & 1 & \\
\hline & Rubiaceae sp. 2 & $\mathrm{Ru}$ sp2 & $\mathrm{U}$ & 1 & \\
\hline & Rubiaceae sp.3 & $\mathrm{Ru} \mathrm{sp} 3$ & $\mathrm{U}$ & & 5 \\
\hline & Rubiaceae sp.4 & Ru sp4 & $\mathrm{U}$ & & 1 \\
\hline & Rubiaceae sp.5 & $\mathrm{Ru} \mathrm{sp} 5$ & $\mathrm{U}$ & & 7 \\
\hline & Rubiaceae sp.6 & Ru sp6 & $\mathrm{U}$ & & 1 \\
\hline Rutaceae & Zanthoxylum petiolare A.St.-Hil. \& Tul. & Z pet & $\mathrm{P}$ & 1 & \\
\hline \multirow{3}{*}{ Salicaceae } & Banara parviflora (A.Gray) Benth. & B par & ST & 1 & \\
\hline & Casearia decandra Jacq. & $\mathrm{C}$ dec & ST & 1 & \\
\hline & Casearia sylvestris Sw. & C syl & $\mathrm{P}$ & & 1 \\
\hline \multirow{3}{*}{ Sapindaceae } & $\begin{array}{l}\text { Allophylus edulis (A.St.-Hil. et al.) Hieron. ex } \\
\text { Niederl. }\end{array}$ & A edu & $\mathrm{P}$ & 12 & \\
\hline & Cupania oblongifolia Mart. & C obl & ST & & 2 \\
\hline & Sapindaceae sp.1 & S sp1 & $\mathrm{U}$ & & 1 \\
\hline Sapotaceae & Diploon cuspidatum (Hoehne) Cronquist & D cus & ST & 1 & 1 \\
\hline Solanaceae & Solanaceae sp.1 & So sp1 & $\mathrm{U}$ & & 2 \\
\hline \multirow{2}{*}{ Urticaceae } & Cecropia sp. & Ce sp & $\mathrm{U}$ & 1 & \\
\hline & Pourouma guianensis Aubl. & P gui & $\mathrm{P}$ & & 2 \\
\hline
\end{tabular}

AB: abbreviation for CCA analysis; SG: successional groups; P: pioneer species; ST: shade tolerant species; U: unclassified;

Nind: number of individuals sampled. 